\title{
リニアパルスモータで駆動される大動脈内バルーンポンプと 両心人工心臟の開発
}

\author{
Development of Artificial Heart and Intra Aortic Balloon Pump \\ Using Linear Pulse Motor \\ 山田 一・佐藤右一*・度会 明*・获田充二**・中川 洋**・前田 豊** \\ 辻 堯***. 森本雅巳***** 湓井雅巳*****三田村好矩****** \\ 信州大学工学部菓気電子工学科・*信州大学大学院電気工学尃攻, 長野市若里 500 (6380)

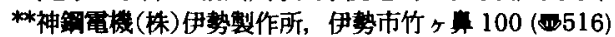 \\ ***日本ぜオン(株)，東京都港区三田 3-13-16 (画152) \\ *****信州大学医学部, 松本市旭 3-1-1 (-390) \\ *****北海道東海大学工学部，札愰市南区南沢五条 1-1-1 (ש005)

\begin{abstract}
H. Yamada, Y. Sato*, A. Watarai*, M. Karita**, H. Nakagawa**, Y. Maeda**, T. Tsuji***, M. Morimoto*****, M. Nirei**** and Y. Mitamura******

**Ise Works, Shinko Electric Co., Ltd., 100 Takegahana-machi, Ise 516

***Nihon Zeon Co., Ltd., 3-13-16 Mita, Minato-ku, Tokyo 152

****Department of Medicine, Shinshu Univ., 3-1-1 Asahi, Matsumoto 390

******Hokkaido Tokai Univ., 1-1-1 5-jyo, Minamisawa, Minami-ku, Sapporo 005
\end{abstract} \\ Faculty of Engineering, Shinshu Univ. and *Graduate Course, Shinshu Univ., 500 Wakasato, Nagano 380
}

This paper deals with Intra Aortic Balloon Pump (IABP) and Artificial Heart (AH) using linear pulse motors (LPM). The characteristics may be summarized as follows. The maximum static thrusts of the LPM for IABP and the LPM for AH are 530 newtons and 107 newtons, respectively. The kinetic thrusts of the LPM for IABP and the LPM for AH are 350 newtons and 67 newtons, respectively. The desired values of the thrust are obtained by experiment. In the mock test, expansion time of balloon in the IABP using the LPM is obtained at $100 \mathrm{~ms}$. Usual IABP system will be miniaturized by the use of the LPM in the future. The instantaneous flow rate of the $\mathrm{AH}$ using LPM can be controlled by acceleration drive pattern of LPM. The AH using LPM can obtained at $5.3 \mathrm{~L} / \mathrm{min}$ at pulse rate of 100 beats $/ \mathrm{min}$ in the mock circulatory test. These flow rates are enough for an adult to live. The temperature rise of the $A H$ is $11^{\circ} \mathrm{C}$, which is recognized as an important problem in suppression of the temperature rise.

Key words: intra aortic balloon pump, artificial heart, linear pulse motor, blood pump, mock circulatory test

\section{1. まえがき}

急性心不全患者の心機能回復には，現在大動脈内バ ルーンポンプ (Intra Aortic Balloon Pump, 以下 IABP と略す）が広く用いられている. しかし，現状ではその
装置が大型のため救急・救命に効果が制限されてい $ろ^{11}$. また，IABPを用いても心機能の回復の見込みのな い患者に対して補助人工心謈があり，将来的には埋込型 人工心臟がとってかわるあのと予想される.

筆者らは，IABP の小型化を図るためにリニアパルス モータ (Linear Puise Motor, 以下 LPM と略す) を用い たシステムを試作した，一方，人工心腊については従来 まで片心人工心脿の基礎研究を続け，今回は改良を加え た LPMを用いた両心人工心騰を開発した.

本論文では，IABP 之両心人工心脿について以下の検 討事項について述べるのである.

1) IABP-LPM-S89 (以下 IABP 用 LPM と略す) と 人工心腈用 LPM の静推力, 効率（動推力）特性.

2) IABP システムの構成およびそれを用いた模擬試 検結果.

3) Artificial Heart-LPM-S90 (以下 AH 用 LPM と 略す）の両側に血液ポンプを取り付けた両心人工心脿の 構造之模擬循環試験装置による性能評価.

4）本人工心臟の温度特性.

\section{2. リニアパルスモータの特性}

\section{1 リニアパルスモータの檴造}

Fig. 1 は LPM の基本構造図を示したものである. 本 LPM は 2 次側可動子を挟む上下 1 対の 1 次側固定子か ら成り，支持機構には耐久性に富むボールが無限に循環 


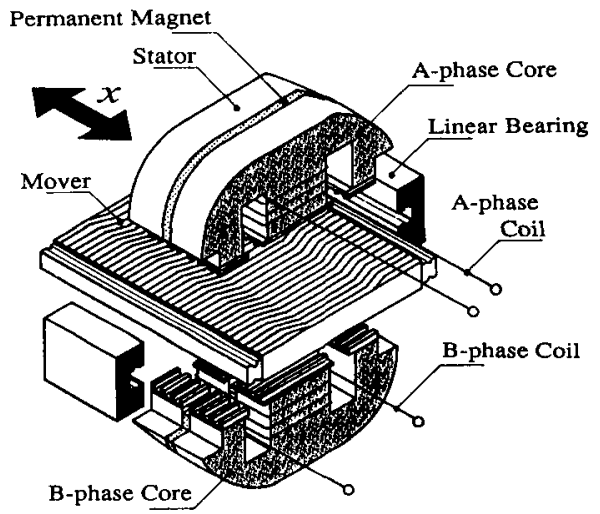

Fig. 1 Configuration of linear pulse motor ( $x$ is displacement).

するリニアベアリングにより，1 次側と 2 次側のエア ギャップを $40[\mu \mathrm{m}]$ に保持している. 永久磁石には, $\mathrm{Sm}$-Co プラスチック磁石を用いている.

IABP 用 LPM は, 上下 1 対の 1 次側固定子で 1 相を 形成しており，左右に 2 組配置されている. ピッチ $\tau=$ $1.6[\mathrm{~mm}]$, 質量は $8.8[\mathrm{~kg}]$ となっている. 材質は, 1 次 側固定子に $0.5[\mathrm{~mm}]$ 厚のケイ素鋼板 (S50)の積層， 2 次側可動子に炭素鋼 (SS41)のブロック材, 㐘は 1 次側, 2 次側共に低炭素鋼 (SPCC)のスリット板を使用してい る.

AH 用 LPM は, 固定子に $0.35[\mathrm{~mm}]$ 厚のパーメン シュール $(49 \% \mathrm{Co}-2 \% \mathrm{~V}-\mathrm{Fe})$ の積層, 可動子はパーメン シュールのフロック材を使用している. パーメンシュー ルは高飽和磁束密度, 高透磁率, 防振特性に優れた材質 である. ピッチ $\tau=0.8[\mathrm{~mm}]$, 体積 $85[\mathrm{~mL}]$, 質量 780 [g]である.

\section{2 リニアパルスモータの静特性}

Fig. 2 は 2 機種の LPM の 2 相励磁における最大静推 力ー励磁電流特性を示したものである, 同図より IABP 用 LPM， $\mathrm{AH}$ 用 LPM は共に励磁電流 $1.5[\mathrm{~A}]$ 付近より 飽和㑯向が見られる。IABP 用 LPM は $3[\mathrm{~A}]$ に招いて 最大静推力 $530[\mathrm{~N}]$ であり, 自己保持力であるディテン ト力は約 $30[\mathrm{~N}]$ であった。

AH 用 LPM の励磁電流 $2[\mathrm{~A}]$ における最大静推力は 107 [N] となり, 従来機 (LPM-S89) と比較して 7\%推力 が向上した，これは，可動子材質が従来の炭素鋼（SS 41 , 最大磁束密度 $B_{\mathrm{m}}=1.7[\mathrm{~T}]$ ] からパーメンジュール $\left(B_{\mathrm{m}}=2.4[\mathrm{~T}]\right)$ に変更したことにより, 可動子内での磁気

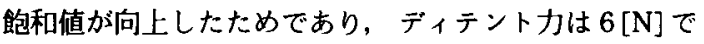
あった。

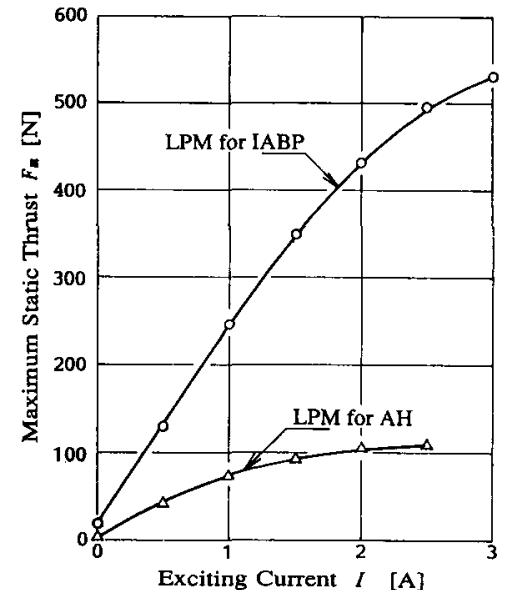

Fig. 2 Characteristics of maximum static thrust, $F_{\mathrm{m}}$, versus exciting current, $I$, at twophase excitaion of LPM for IABP and LPM for artificial heart.

Table 1 Principal characteristics of two linear pulse motors for IABP and $\mathrm{AH}$

\begin{tabular}{l|cc|c|c}
\hline \multicolumn{1}{c|}{ Item } & \multicolumn{2}{c|}{ Symbol [unit] } & LPM for IABP & LPM for AH \\
\hline Static thrust & $F_{m}$ & {$[\mathrm{~N}]$} & 530 & 107 \\
Exciting current & $I$ & {$[\mathrm{~A}]$} & 3 & 2 \\
Input power & $P_{i}$ & {$[\mathrm{~W}]$} & 16.2 & 4.8 \\
Volume & $V$ & {$[\mathrm{~mL}]$} & 1756 & 85 \\
Mass & $H$ & {$[\mathrm{~g}]$} & 8800 & 780 \\
\hline Thrust/Input ratio & $F_{m} / P_{i}[\mathrm{~N} / \mathrm{W}]$ & 32.6 & 22.3 \\
Thrust/Volume ratio & $F_{m} / V[\mathrm{~N} / \mathrm{mL}]$ & 0.30 & 1.26 \\
Thrust/Mass ratio & $F_{m} / M[\mathrm{~N} / \mathrm{g}]$ & 0.06 & 0.14 \\
\hline
\end{tabular}

L:liter

Table 1 は IABP 用 LPM と AH 用 LPM の特性値の 比較を示したものである. 同表から最大静推力/入力電 力比はいずれの LPM も $20[\mathrm{~N} / \mathrm{W}]$ 以上の高い特性値を 有していることが分かる.

\section{3 リニアパルスモータの動特性}

リニアモータの出力 $P_{\mathrm{o}}$ は次式で与えられる.

$P_{\mathrm{o}}=F_{\mathrm{k}} v[\mathrm{~W}]$

ここに, $F_{\mathrm{k}}$ : 動推力 $[\mathrm{N}]$,

$$
v: \text { 速度 }[\mathrm{m} / \mathrm{s}]
$$

したがって，モータの効率 $\eta$ は，次式となる.

$$
\eta=\frac{P_{\mathrm{o}}}{P_{\mathrm{i}}} \times 100=\frac{F_{\mathrm{k}} v}{P_{\mathrm{i}}} \times 100[\%]
$$

\section{ここに, $P_{\mathrm{i}}$ : 入力電力 $[\mathrm{W}]$}

$\mathrm{AH}$ 用 LPM はマイクロステップ駆動（フルステップ 駆動の $1 / 50$ のステップ) のため, 速度 $v$ は次式となる. 


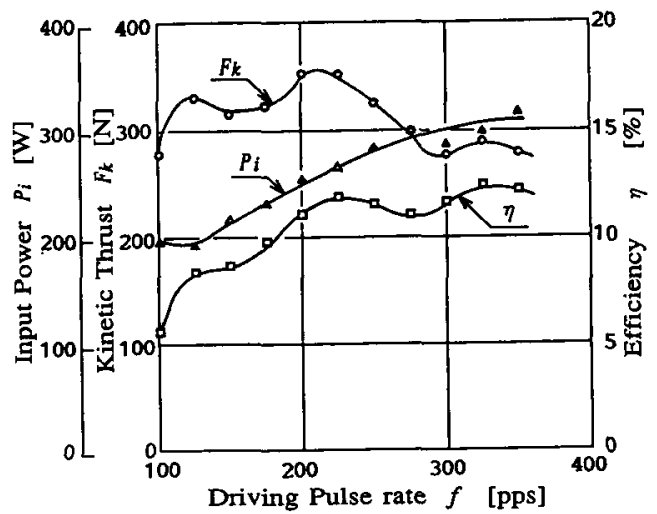

Fig. 3 Efficiency characteristics of LPM for IABP.

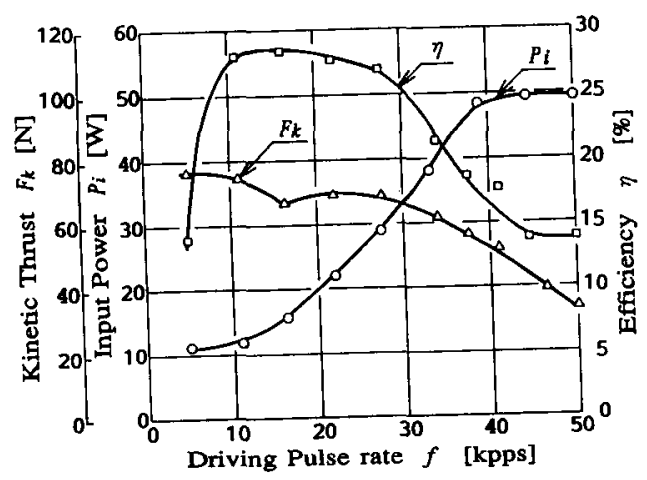

Fig. 4 Efficiency characteristics of LPM for artificial heart.

$$
v=\frac{f}{50} \cdot \frac{\tau}{4}[\mathrm{~m} / \mathrm{s}]
$$

ここに, $f:$ 駆動周波数 [pps],

$$
\tau: \text { ピッチ }[\mathrm{m}]
$$

2.3.1 IABP 用 LPM の効事 Fig. 3 は励磁電流 4 [A]，フルステップ取動，直列接続におけるIABP 用 LPM の効率を示したものである. 同図より IABP 用 LPM は取動周波数 200 [pps]において最大動推力 350 [N]を発生していることが明らかになった。また IABP 用 LPM を駆動装置として使用する場合の周波数 250 350 [pps]の範囲においての効率は約 12 [\%]が得られ た.

2.3.2 AH 用 LPM の効事 Fig. 4 は励磁電流 $2[\mathrm{~A}]$ における AH 用 LPM の効率を示したものである. 同図 より人工心脿としての動作籍囲である取動周波数 17〜 32 [kpps] (拍動数 60 100 [bpm]) において, 動推力が
約 $65[\mathrm{~N}]$ ，入力電力 35 [W] 以下となり，効率が 25 [\%] 以上となった，IABP 用 LPM と比較して高効率である のは，材質の飽和磁束密度が高いこと，可動子の質量， ピッチてが小さいことによる. また，駆動方法がマイク ロステップ駆動であるため, フルステップ駆動より推力 の脈動が小さくなり，動推力の低下が低減されただとと 考えられる.

\section{IABP の特性}

\subsection{IABP の概要}

IABP とは心腈疾患である循環不全に相当する心筋の 心力不全で弱った心脿を機械的に補助および心膕機能回 復を目的とした補助循環装置である゙?.

Fig. 5 は大動脈内にバルーンを挿入したときのモデル を示したものである. 生体外部に置かれた駆動装置に接 続されているバルーンを手術により大動脈内に乗入す る. 大動脈内に挿入されたバルーンは心稢の拡張期にお いて収縮し，また心腈の収縮期においては拡張し血液の 流れを補助するものである．使用されるバルーンの容量 は，挿入される人間の体格により異なるが，一般に日本 人の成人では $40[\mathrm{~mL}]$ のものが使用されている.

\subsection{IABP の模提式硂}

Fig. 6 はIABP 用 LPM を使用したときのIABP シス テムの構成を示したものである ${ }^{3)}$. LPM の可動子に直接 ベローズを連結し, 可動子の往復運動をべローズに伝達 し, ベローズ内の空気圧で模擬試験装置内のバルーンの 収縮，拡張が行われる。なお模擬試験装置は大動脈を模

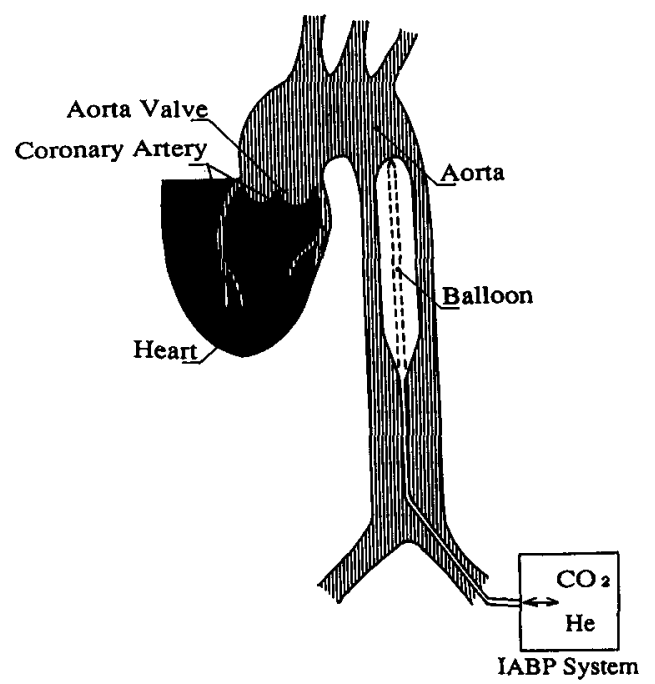

Fig. 5 Constitution of IABP system. 
擬したあのである゙．以下に測定条件を示した。

1) LPM の励磁電流 4 [A]，フルステップ加減速駆 動, ストローク $15[\mathrm{~mm}]$

2) バルーン容量 $60[\mathrm{~mL}]$

3) バルーンの拡張期/収縮期 $=1$

4）模擬試験装固内圧 $40[\mathrm{mmHg}$ ，水頭圧 $75[\mathrm{~mm}]$ 圧力波形はべローズ内の圧力 $P$ を圧力センサを介し て，また变位 $x$ はポテンショメータを用いレコーダによ り測定を行った。

Fig. 7(a) は模擬試験における駆動圧力一時間特性, 同 図 (b) は変位-時間特性を示したものである，同図 (a) に おいて圧力のピーク值は $280[\mathrm{mmHg}]$ ，バルーン収縮期 直前の圧力値は $140[\mathrm{mmHg}]$ であり，血圧の㫒圧には 十分と考えられる．また同図 (b)においてバルーン拡張

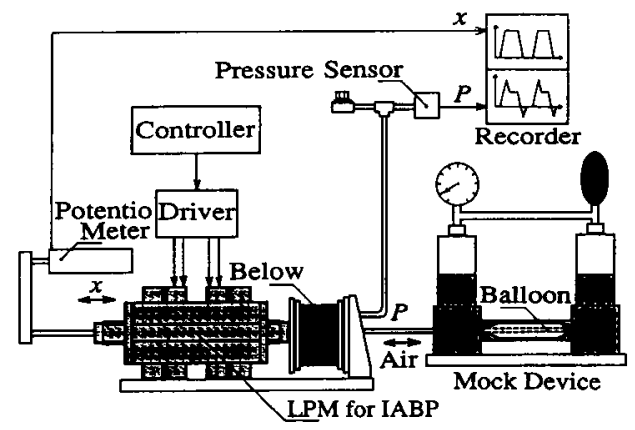

Fig. 6 IABP system using LPM for IABP.

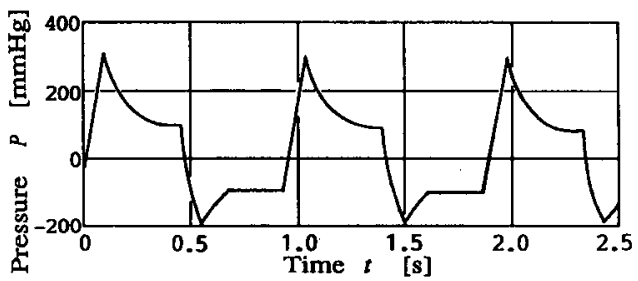

(a)Pressure versus time characteristic

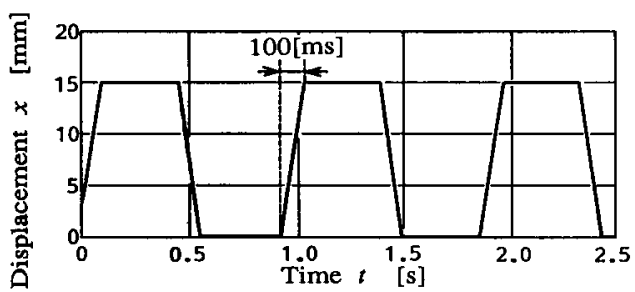

(b)Displacement versus time characteristic

Fig. 7 Mock test of IABP system using LPM for IABP.
時間は $100[\mathrm{~ms}]$ であり，初期の目標は達成することが できた. Fig. 3 より駆動周波数の増加に伴い推力が減少 する傾向が見られた．このため駆動周波数の低い方から 可動子を始動させた方が動推力を得るためには有利と思 われる，特に始動時においては，ベアリングの摩擦や可 動子の慣性力による損失が大きいため可動子の運動時よ り動推力を必要とする。したがって，可動子の始動時に は低い周波数のパルスを入力し，始動後に高い周波数の パルスを入力することにより，LPM を一定周波数で駆 動するより高い速度で駆動することが可能であることが 明らかとなった。

\section{4. 両心人工心灌の特性}

\section{1 两心人工心䑏の棈造}

Fig. 8 はリニアパルスモー夕駆動型両心人工心葴の構 造を示したものである゙5. LPMの両側には，それぞれ血 液ポンプをアルミニウムハウジングで接合してある．血 液ポンプはストローク $20[\mathrm{~mm}]$, 一回拍出量 $60[\mathrm{~mL}]$ である.人工弁は流入口に $20[\mathrm{~mm}]$, 流出土に $18[\mathrm{~mm}]$ のオムニカーボン弁を用いている，LPM の可動子に取 り付けたプッシャプレートの往復運動により液体の拍出

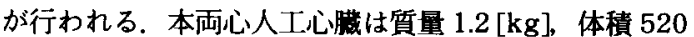
[mL]である.

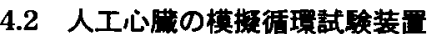

Fig. 9 は簡易模擬循環試験装置の構造および流量測定 ブロック線図を示したものである，模擬循環試験装置と は, 生体循環器系の模撕試験の一種である ${ }^{6}$. 同図は生体 の左心系と右心系を模擬したシステムであり，両心人工 心蔵を接続することによりシステムが完成する，左心系 の大動脈パイプは平均大動脈压を $80[\mathrm{mmHg}]$ から 120 $[\mathrm{mmHg}]$ まで $10[\mathrm{mmHg}]$ ずつ変更できる構造としてお る. 右心系の肺動脈圧は $40[\mathrm{mmHg}]$ とした，模擬循環 試験装置にはドノバン (Donovan) 型などあるが，オー バフロー式の本試験装置はパイプの直径と長さを決めれ ばその特性は一定不変となる装置である。したがって, いずれの人工心㖑であ同一条件で試験を行うことができ る. 大動脈パイプの接続部に流量センサを取り付け，本 人工心堿による水の拍出を電磁血流計で測定する. LPM の制御はコントロールとドライバからなる駆動シ ステムにより行われる。

\section{3 両心人工心䑄の特性}

Fig. 9 に示した測定方式により本両心人工心满の性能 を評価した，以下に，測定条件を示した。

1) 人工心脿の収縮期/搪張期 $=1$

2）LPMはマイクロステップ加減速駆動（バイポー 


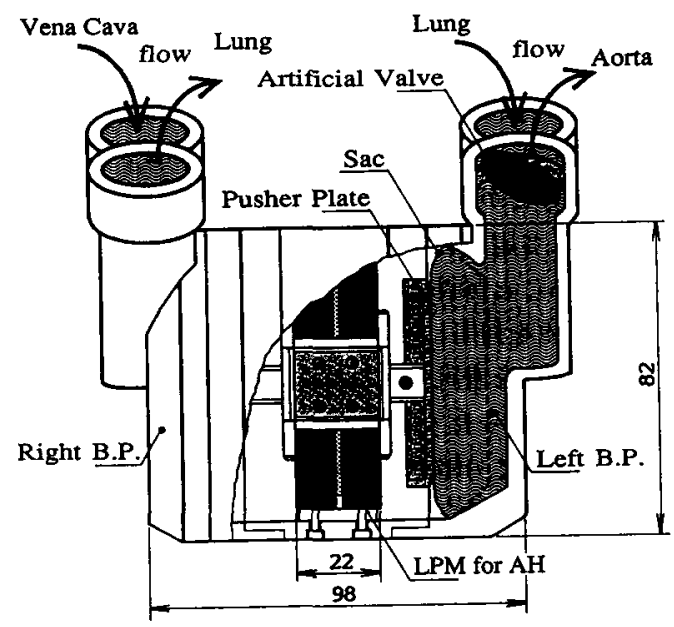

Fig. 8 Artificial heart using LPM-driven A.H. with two ventricles (B.P., Blood Pump; unit, mm).

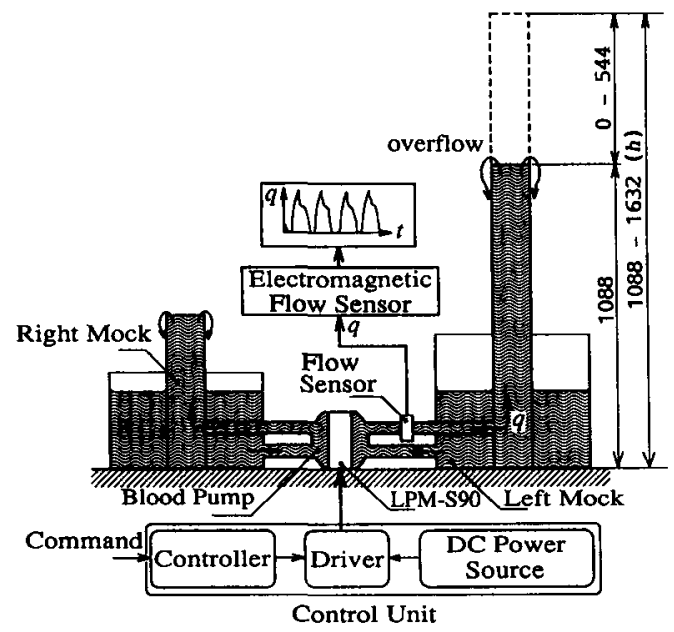

Fig. 9 Mock circulatory test of LPM for AH driven artificial heart (unit, $\mathrm{mm}$ ).

ラチョッパ定電流方式)，励磁電流 2 [A]， スト ローク $18[\mathrm{~mm}]$

3) 平均大動脈生 $80[\mathrm{mmHg}]$

4) 血液ポンプの流入厈力である心房圧は左心系, 右 心系共に $13[\mathrm{mmHg}]$

Fig. 10 は平均大動脈圧 $80[\mathrm{mmHg}]$ の条件で LPM を加減速駆動させた場合の瞬時流量波形を示したもので ある. 加减速駆動とは，始動時に動推力の大きい低速で 駆動することにより，LPM の始動不能防止を目的とし た一つの方法である. 同図より拍動数 $60[\mathrm{bpm}]$ で分時
流量 $3.3[\mathrm{~L} / \mathrm{min}]$, 拍動数 $100[\mathrm{bpm}]$ では分時流量 5.3 $[\mathrm{L} / \mathrm{min}]$ が得られた，また，従来の等速駆動時に見られ た弁の 2 度打ちゃパイブ内での水の乱流の影響が減少 しだ.これは, 加減速駆動により流量の立ち上がりが滑 らかになったためと考えられる。これより，LPMの速 度駆動パターンを変化させることにより, 瞬時流量波形 を制御できることが明らかとなった。

Fig. 11 は本両心人工心腊の分時流量一拍動数特性を 示したものである. 分時流量は二つの速度駆動パターン による大きな違いは見られなかった，同図より，拍動数 $H_{\mathrm{r}}$ 之分時流量 $Q$ は, 次式で示される関係となった。

$$
Q=0.05 \times H_{\mathrm{r}}+0.5[\mathrm{~L} / \mathrm{min}]
$$

拍動数 $100[\mathrm{bpm}]$ における分時流量は $5.3[\mathrm{~L} / \mathrm{min}]$ が 得られ，成人に対して十分な流量が達成された。

\section{4 両心人工心灌の温度特性}

人工心裁を生体内に埋込む場合, その温度上昇は周辺 紐胞組織の壊死を招く，そのために，アクチェエータの 温度上昇は極力低くしなければならないとされている。

Fig. 12 は AH 用 LPM 単体之両心人工心脿の模擬循 環試験を行っている時のハウジング表面の温度特性を示 したものである，測定条件は，マイクロステップ等速駆 動, 励磁電流 $1.5[\mathrm{~A}]$ ，拍動数 $80[\mathrm{bpm}]$ （駆動周波数 27.5 [kpps])，室温・水温 $24^{\circ} \mathrm{C}$ である. 同図より， $\mathrm{AH}$ 用 LPM 単体の場合, 盷和温度は $56^{\circ} \mathrm{C}$ (温度上昇 $32^{\circ} \mathrm{C}$ ) となった，また，模擬循環試験時には，耐えず水の循罯 で冷却しているため飽和温度は $35^{\circ} \mathrm{C}$ (温度上昇 $11^{\circ} \mathrm{C}$ )

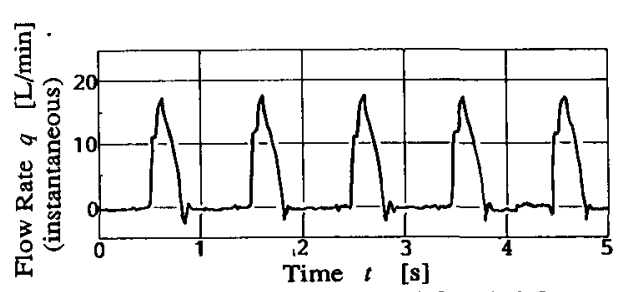

(a) $H_{r}=60[\mathrm{bpm}], Q=3.3[\mathrm{~L} / \mathrm{min}]$

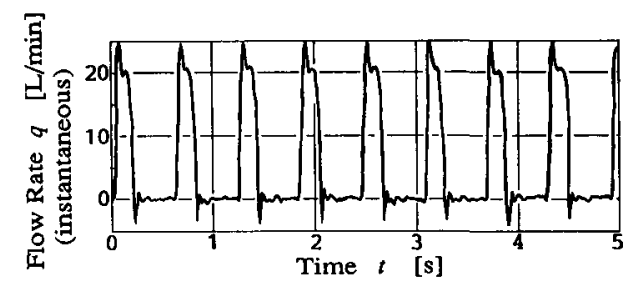

(b) $H_{r}=100[\mathrm{bpm}], Q=5.3[\mathrm{~L} / \mathrm{min}]$

Fig. 10 Instantaneous flow rate, $q$, versus time, $t$, characteristics of the artificial heart (LPM for AH). (Microstep acceleration drive.) 


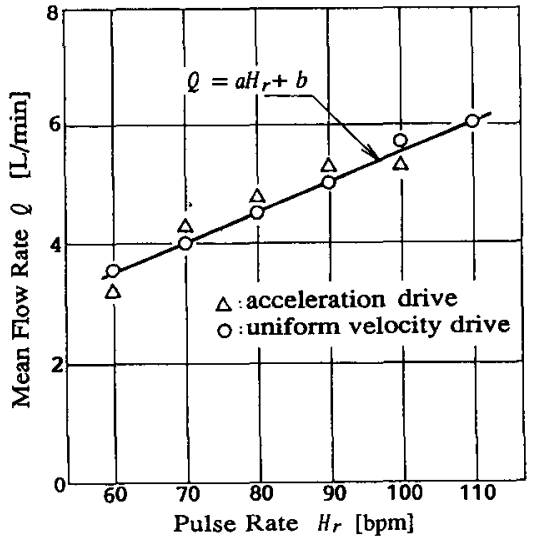

Fig. 11 Relationship between mean flow rate, $Q$, and pulse rate, $H_{\mathrm{r}}$, of artificial heart (LPM for AH). $(a=0.05, b=0.5)$

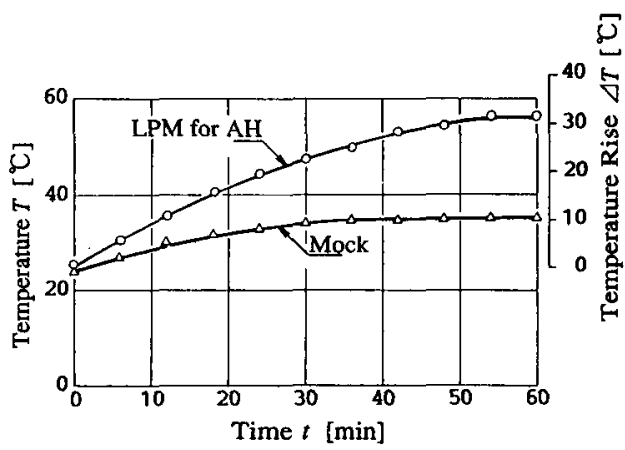

Fig. 12 Characteristics of temperature rise, $\Delta T$, on housing versus time, $t$, of artificial heart (LPM for $\mathrm{AH}$ ).

であった。

\section{5. あとがき}

リニアパルスモータで駆動される大動脈内バルーンポ ンプと両心人工心脿の 2 特性をまとめると以下のよう になる。

1) IABP 用 LPM と AH 用 LPM の 2 相励磁におけ る最大静推力はそれぞれ $530[\mathrm{~N}]$ と $107[\mathrm{~N}]$ となった。
その動推力はそれぞれ $350[\mathrm{~N}]$ と $67[\mathrm{~N}]$ であり, 所定 の推力が得られた.

2）IABP 模擬試験の結果より，既に市販されている IABP 装置のバルーンの拡張時間 $100[\mathrm{~ms}]$, が得られ た.このことから、IABP 用 LPM を駆動用アクチュ エータとして用いることにより，IABP 装置の小型化が 可能であることが明らかとなった。

3）LPM を利用した両心人工心祴においては，LPM に加減速駆動を適用することにより，瞬時流量波形の制 御が可能となった，本両心人工心臟は，拍動数 100 [bpm]において分時流量 $5.3[\mathrm{~L} / \mathrm{min}]$ となり, 成人に対 し十分な流量が得られた。

4) 本両心人工心䴇の温度上昇は $11^{\circ} \mathrm{C}$ であり，さら に温度上昇を抑えることが必要となろう。

本研究の一部は, 厚生省受託研究費の“慢性重症心不 全患者に対する永久使用人工心腈の開発研究”および “長野県テクノハイランド開発機関研究助成金”によっ て行われた。

\section{文献}

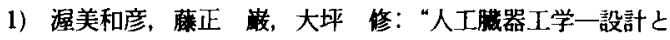
開発の方法論一", p. 8, 講談社, 東京 (1988).

2）桜井靖久：“医用工学 (ME) の基礎と応用”，p. 43，共立出 版, 東京 $(1980)$.

3）山田一，度会 明，荻田充二，辻 堯，森本雅已，榆 井雅已：第 14 回日本応用磁気学会学術講演概要集, p. 427 (1990).

4）山田 一, 西脇重弘, 森本雅巳，莸田充二, 中川 洋, 前 田 豊, 辻 芬: 電気学会マグネティックス・リ二アト ライフ合同研究会盗料，MAG-89-178，LD-89-33，p. 23 (1989).

5）山田一，佐藤右一，获田充二，中川 洋, 前田 䅱, 三 田村好矩：第 14 回日本応用磁気学会学術講演概要集, $p$. 426 (1990).

6) 荻田充二, 佐藤右一, 山田一: 日本応用磁気学会誌, 14, 483 (1990).

7) 传藤右一, 山田 一, 荻田充二, 中川 洋, 前田 患: 第 2 回リニアドライブ若手研究者シンポジムム資料，S90-8 (1990).

1990 年 12 月 3 日受理, 1991 年 2 月 28 日採録 